\title{
Structure and Surface Reactivity Mediated Enzymatic Performances of Clay-Based Nanobiocatalyst
}

\author{
S. Sun ${ }^{(凶)}$, K. Wang, F. Dong, B. Ma, T. Huo, Y. Zhao, H. Yu, \\ Y. Huang, and J. Huang \\ Institute of Non-metallic Minerals, Department of Geological Engineering, \\ School of Environment and Resource, Southwest University of Science \\ and Technology, Mianyang, People's Republic of China \\ shysun@swust.edu.cn
}

\begin{abstract}
The nanobiocatalyst is an emerging innovation that synergistically integrates advanced nanotechnology with biotechnology for improving enzyme activity, stability, capability and engineering performances. Enzymes and clay minerals are two important essential substances in the earth. As the important nanostructured minerals, clay minerals have played an important role in enzymerelated biochemical processes such as the origin and evolution of life, soil ecological environment, pollution remediation and element geochemical cycling, and even some clay minerals have intrinsic enzymatic activities. Based on the study of clay minerals-based enzyme-like activities and enzymatic catalysis in confined environment by clay minerals, lipase and 3-aminopropyltriethoxysilane (APTES) functionalized montmorillonite (Mt) were selected to biomimetic construct lipaseMt nanobiocatalyst. Experimental results indicated that lipase-Mt activity was $40.65 \mathrm{U} / \mathrm{mg}$, which was nearly 4-fold higher than that of free lipase under optimal conditions. The kinetic parameters of $\mathrm{K}_{\mathrm{m}}$ and $\mathrm{V}_{\max }$ for lipase-Mt were $3.406 \mathrm{mM}$ and $312.5 \mathrm{mM} / \mathrm{L} \mathrm{min}$, respectively, indicating a higher affinity of the immobilized lipase in nanobiocatalyst towards the substrate compared with free lipase. The present study has provided a promising way for screening, optimizing and rational design of efficient nanomineral-based enzymatic nanobiocatalyst. The present work was supported by the National Natural Science Foundation of China (41672039). The Longshan Academic Talent Research Support Program of the Southwest University of Science and Technology (18LZX405).
\end{abstract}

Keywords: Surface reactivity $\cdot$ Clay minerals $\cdot$ Enzyme $\cdot$ Surface modification $\cdot$ Nanostructured minerals $\cdot$ Nanobiocatalyst 
Open Access This chapter is licensed under the terms of the Creative Commons Attribution 4.0 International License (http://creativecommons.org/licenses/by/4.0/), which permits use, sharing, adaptation, distribution and reproduction in any medium or format, as long as you give appropriate credit to the original author(s) and the source, provide a link to the Creative Commons license and indicate if changes were made.

The images or other third party material in this chapter are included in the chapter's Creative Commons license, unless indicated otherwise in a credit line to the material. If material is not included in the chapter's Creative Commons license and your intended use is not permitted by statutory regulation or exceeds the permitted use, you will need to obtain permission directly from the copyright holder.

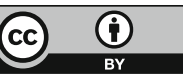

